Case report

\title{
A Complex Rare Presentation of Rice Tablet Poisoning: A Case Report
}

\author{
Feridoun Sabzi, Aghigh Heydari, Reza Heidari Moghaddam, Mohammad Rouzbahani, \\ Atefeh Asadmobini
}

Cardiovascular Research Center, Kermanshah University of Medical Sciences, Kermanshah, Iran

\author{
SUMMARY
}

\begin{abstract}
Aluminum phosphide, known as "rice tablet” (RT), is a common cause of suicide in adult women in Iran, with a high rate of lethal outcome. We report a patient with RT toxicity, with a complex syndrome of hepatic failure, renal failure, Brugada electrocardiography (ECG) patterns, and pleuropericardial effusion. The patient received conventional management with fluid therapy, gastric washing, activated charcoal followed by intra-aortic balloon pump insertion, inotropic drugs support, and mechanical ventilation. The unique features of our case are related to a combination of multiorgan failure with Brugada atypical ECG patterns and pleuropericardial effusion. Among the aforementioned complications, pleuropericardial effusion, ascites, and Brugada syndrome are exceedingly rare events. The patient was treated with high-dose inotropic drugs and intra-aortic balloon pump insertion. Despite tremendous management of metabolic acidosis, all efforts failed, and the patient died with sudden cardiac arrest.
\end{abstract}

Key words: aluminium phosphide, Brugada syndrome, poisoning

Corresponding author:

Atefeh Asadmobini

e-mail: a.asadmobini@gmail.com 


\section{INTRODUCTION}

It is supposed that mitochondrial damage by rice tablet (RT) containing aluminium phosphide contributes to cellular injury in a solid organ, endothelial cell injury in the vascular system and lung alveolar system. The damage of endothelial cells in the vascular and serous surface of the organ leads to a leak of fluid to interstitial tissue and contributes to pleural effusion, pulmonary edema, brain edema, and severe hypotension (1). We managed an exceptional case with acute RT poisoning who developed myocarditis with atypical Brugada electrocardiography (ECG) patterns, concurrently with hepatic and renal failure, pleuropericardial effusion, ascites, and lethal ventricular fibrillation. This is an exceptional complication of RT and careful study of literature on pleuropericardial effusion revealed some rare cases of concurrent association of myocarditis with hepatic failure and pleuropericardial effusion.

\section{CASE REPORT}

A 35- year-old woman with ingestion of three rice tablets two hours before admission was referred to our hospital. She had constricting chest pain with multiple episodes of vomiting, anxiety and restlessness. Resuscitative efforts for cardiogenic shock were started after taking blood samples for laboratory examination. The patient received one liter of lactated Ringer quickly along with the placement of oxygenation mask. Repeated gastric wash was performed and charcoal tablets were left in the stomach. Intravenous hydrocortisone in a dose of $100 \mathrm{mg}$ was also started. In the first physical examination, she was found to be conscious and fully oriented. Her blood pressure and pulse rates were $170 / 80 \mathrm{mmHg}$ and 110 per minute, respectively. Cardiac exam, except for tachycardia, was unremarkable. Chest exam showed fine bilateral lower lung zones crackles. Although the initial exam was normal, she suffered from abdominal upset, and six hours later tense ascites was detected. The patient's chest pain was similar to the symptoms of ischemic heart disease and was associated with reduced pulse pressure time interval which was responsive to sublingual nitrocontin. Six hours after admission, her anxiety increased and was followed by respiratory distress and cyanosis. She was intubated and connected to a ventilator. With deterioration of the patient's hemodynamic condition and cardiogenic shock (blood pressure decreased to $70 / 50 \mathrm{mmHg}$ and pulse rate increased to 150 pulses per minute), she received a high dose of inotropic drugs (adrenalin, 40 micro per minute and dopamine, 20 micro per minute), and an intra-aortic balloon pump was inserted. Transthoracic echocardiography revealed diffuse hypokinesia of the left ventricle and interventricular septum. Estimated ejection fraction was $25 \%$. Despite ventilator assistance with FIo2 of 100\%, the patient's arterial blood gas tremendously deteriorated with reduced arterial oxygen saturation $(75 \%)$ and metabolic acidosis. When she was under ventilator support, despite hourly correction of metabolic acidosis and anes-

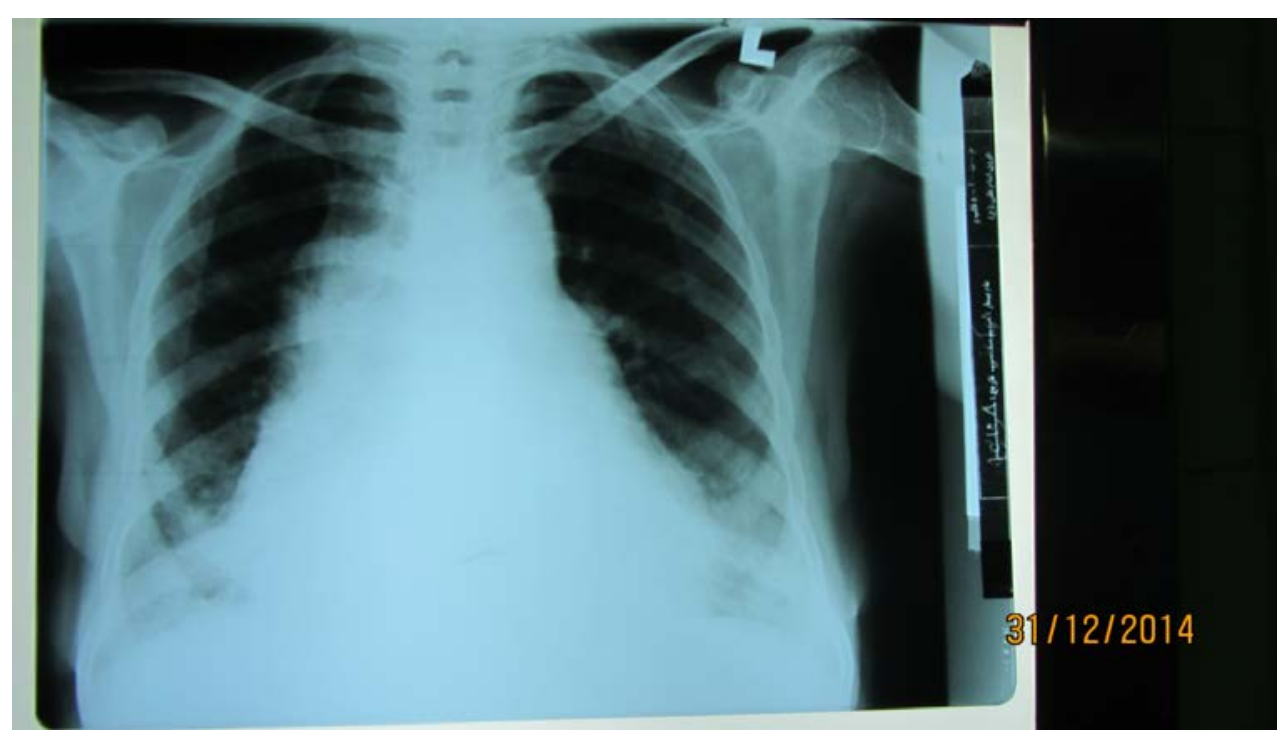

Figure 1. Bilateral pleural effusion is shown 


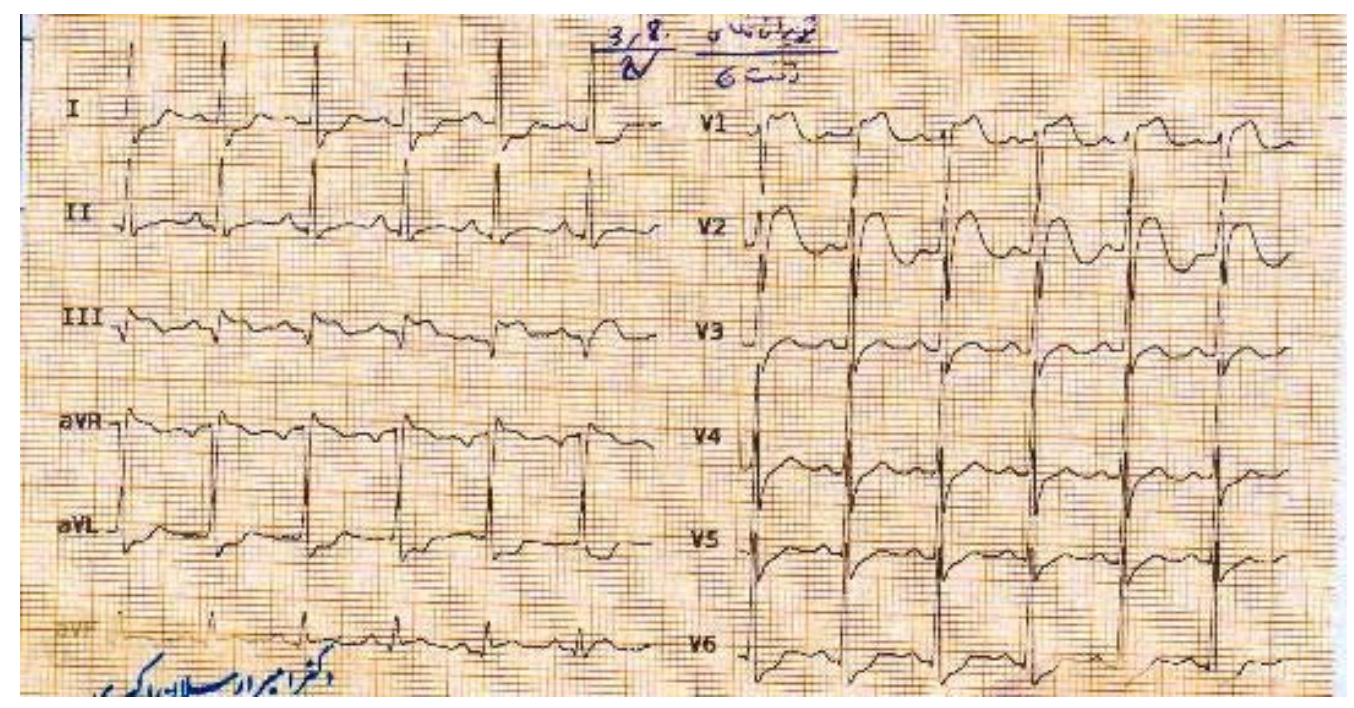

Figure 2. The figure shows S-T segment elevation in V1-V2 leads

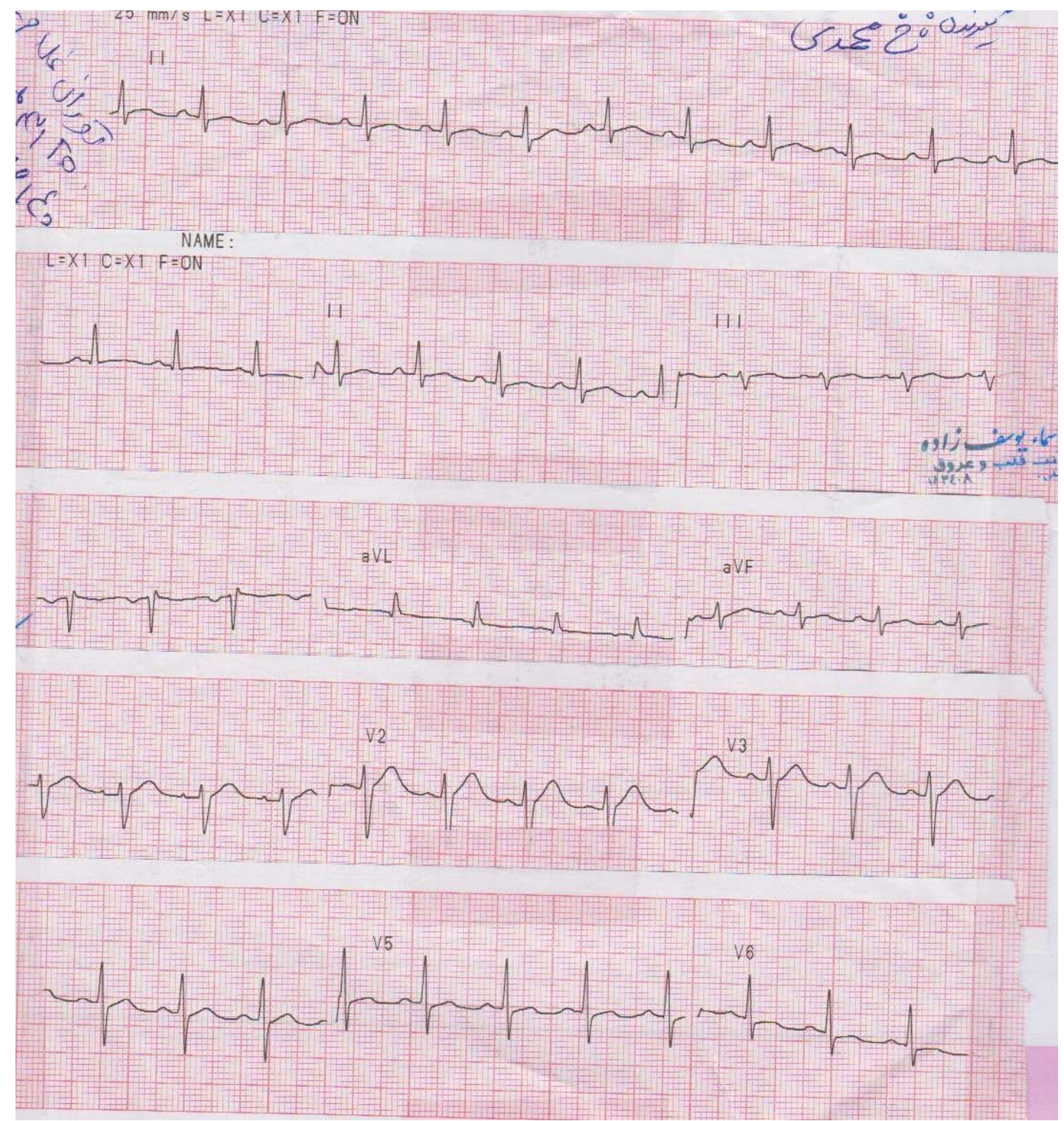

Figure 3. The figure shows the recovery of S-T elevation 
thetic sedation, she became cyanotic with a copious tracheal secretion that was not cleared despite repeated tracheal suction. A portable chest $\mathrm{x}$-ray revealed diffuse pulmonary edema spreading throughout the field of both lungs with pleural effusion blunting both costophrenic angles (Figure 1). Needle aspiration of the pleural fluid showed a whitecolored fluid with protein $4.1 \mathrm{~g} / \mathrm{dl}$ and glucose 50 $\mathrm{mg} / \mathrm{dl}$. Inspection of the 12-lead ECG tracing showed atypical Brugada syndrome with downsloping STsegment elevation in leads V1-V2, consistent with a type-I Brugada syndrome (Figure 2). Repeated TTE via inferior costal view revealed severe reduction of overall cardiac ejection fraction in the form of global hypokinesia without any valvular abnormality. Initial hypokinesia commenced in the infero-lateral wall of left ventricular walls, while soon other segments started to decrease wall motion and led to hypokinesia. ECG that was taken six hours later showed some recovery of the ST segment (Figure 3). TTE via inferior costal view revealed severe reduction of overall cardiac ejection fraction (EF) in the form of global hypokinesia without any valvular abnormality. TTE detected a low EF of $20 \%$ associated with moderate right ventricular dysfunction and pericardial effusion. Despite intra-aortic balloon pump (IABP) and inotropic drug use, no improvement was obtained over the next hours. The patient's hemodynamic condition further deteriorated, and she finally went into irreversible shock so that her pulse and blood pressure were not detectable. Despite volume administration and receiving high dose of triple inotropic drugs and intraaortic balloon pump, her rhythm converted to electromechanical dissociation, and the detected pulse on the monitor was related to IABP pulse pressure. Laboratory test was as follows: normal hemoglobin (13.5 g/dl), Na:126 (range 135 to $145 \mathrm{mmol} / \mathrm{l}$ ) K:4 (range 3.5 to $5 \mathrm{mmol}$ ), magnesium $1 \mathrm{mmol} / \mathrm{l}$ (range 0.6 to 1.1 ) normal coagulation profile, metabolic acidosis (base deficit 39, lactates $23 \mathrm{mmol} / \mathrm{L}$ ) and normal blood sugar, but $\mathrm{CPK}$ and troponine value serially increased. Gradual rising of liver function test was found, so serum levels of aspartate aminotransferase (AST) and alanine aminotransferase (ALT) and alkaline phosphatase (ALP) tremendously increased. The blood urea nitrogen (BUN) and creatinine were increased to $3 \mathrm{mg} / \mathrm{dl}$ and $79 \mathrm{mg} / \mathrm{dl}$, respectively, but serum level of amylase did not rise. Ten hours after admission, she continued to be oliguric with metabolic acidosis, low arterial blood saturation, and low blood pressure. The patient received heparin as a bolus dose of 1000 units followed by 1000 units/h, with the goal of activating the clotting time of $180-200$ seconds. The patient died 48 hours later as a result of cardiogenic shock and multiorgan abnormalities.

\section{DISCUSSION}

RT poisoning is a common cause of suicide in Iran among all community layers (2). The widespread availability of RT in any store and its use as a strong pesticide in bags of rice has increased the rate of successful suicide in the country in the last decade. Unique chemical properties of RT, such as rapid change of solid phase to gas, gradual and persistent release of phosphine gas, odourlessness and its strong effect make this tablet the insecticide of choice for household use in stored rice container (3). Compared to the highest incidence of RT poisoning among the males in other countries, in Iran this form of poisoning is commonly seen among females as an agent in attempting to commit suicide. Over the past decades, the incidence of RT poisoning patients has increased with a high mortality rate due to RT strength, the speed of its effect, and easy availability. Primary clinical manifestation of RT poisoning includes acute gastrointestinal upset caused by phosphine gas that leads to nausea and severe vomiting with rapid absorption of phosphine gas by gastric mucosa and systemic circulation, capillary leakage by endothelial cells, and damage of the vascular system. The symptoms of phosphine poisoning usually develop rapidly, and the majority of deaths occur usually due to cardiovascular arrest (4). Pathophysiologic consequences of phosphine gas absorption are mitochondrial damage, cell hypoxia, and cell death. Due to the huge demand of cardiac muscle for oxygen, myocardium is the first organ that is affected by phosphine gas. Cardiac depression and low cardiac output subsequently damage the poisoned and hypoperfused organs, like kidneys and liver. On the other hand, breaking of first defensive barrier (vascular endothelium) by phosphine gas leads to the accumulation of fluid in the interstitial tissue and severe hypotension and metabolic acidosis (5). Both interstitial edema by capillary leakage and hypoxic edema caused by hypoperfusion together with low cardiac output lead to further organ hypoperfusion and organ failure (6). Mitochondrial injury of myocardial cells not only leads to myocardial cell edema 
but is associated with inflammation and cell hypoxia. This process also involves various types of conduction defect that presents as a right, left, or complete bundle branch block (6). In exceptional cases, coronary artery spasms manifest themselves as Brugada syndrome. Why this coronary spasm is limited to the right anterior leads remains unknown. Other rare sequels of cardiac involvement are a wide range of arrhythmias, pericarditis and effusion (7). Accompanying pulmonary involvement including cardiogenic and non-cardiogenic pulmonary edema that presents in the form of diffuse interstitial pul- monary edema may lead to intractable respiratory failure. Other pulmonary sequels of APP are severe hemoptysis, tracheobronchial edema, interstitial lung hemorrhage and pleural effusion $(8-12)$.

\section{CONCLUSION}

We conclude that in cases of rice tablet poisoning, the patients may present with a wide range of complications; however, the combination of serositis with Brugada ECG patterns is an exceptional phenomenon.

\section{References}

1. Lemoine TJ, Schoolman K, Jackman G, et al. Unintentional fatal phosphine gas poisoning of a family. Pediatr Emerg Care 2011; 27(9):869-71. https://pubmed.ncbi.nlm.nih.gov/21926889/

2. O'Malley $M$, Fong $H$, Sánchez $M E$, et al. Inhalation of phosphine gas following a fire associated with fumigation of processed pistachio nuts. J Agromedicine 2013; 18(2):151-73. https://pubmed.ncbi.nlm.nih.gov/23540306/

3. Rodenberg HD, Chang CC, Watson WA. Zinc phosphide ingestion: a case report and review. Vet Hum Toxicol 1989; 31(6):559-62. https://pubmed.ncbi.nlm.nih.gov/2575817/

4. Shadnia S, Rahimi M, Pajoumand A, et all. Successful treatment of acute aluminium phosphide poisoning: possible benefit of coconut oil. Hum Exp Toxicol 2005;24(4):215-8.

https://pubmed.ncbi.nlm.nih.gov/15957538/

5. Misra UK, Tripathi AK, Pandey R, et al. Acute phosphine poisoning following ingestion of aluminium phosphide. Hum Toxicol 1988; 7(4):343-5.

https://pubmed.ncbi.nlm.nih.gov/3410483/
6. Mehra A, Sharma N. ECMO: A ray of hope for young suicide victims with acute aluminum phosphide poisoning and shock. Ind heart J; 2016:68(3):256.

https://pubmed.ncbi.nlm.nih.gov/15957538/

7. Musshoff F, Preuss J, Lignitz E, et al. A gas chromatographic analysis of phosphine in biological material in a case of suicide. Forensic Sci Int 2008; 177(2-3):35-8. https://pubmed.ncbi.nlm.nih.gov/18294792/

8. Anger F, Paysant F, Brousse F, et al. Fatal aluminum phosphide poisoning. J Anal Toxicol 2000; 24(2):90-2.

https://pubmed.ncbi.nlm.nih.gov/10732945/

9. Yadav J, Athawal BK, Dubey BP, et al. Spontaneous ignition in case of celphos poisoning. Am J Forensic Med Pathol 2007; 28:353-5 .https://pubmed.ncbi.nlm.nih.gov/18043026/

10. Anand R, Binukumar BK, Gill KD. Aluminum phosphide poisoning: an unsolved riddle. J Appl Toxicol 2011; 31(6):499-505.

https://pubmed.ncbi.nlm.nih.gov/21607993/ 
11. Harger RN, Spolyar LW. Toxicity of phosphine, with a possible fatality from this poison. AMA Arch Ind Health 1958; 18(6):497-504. https://pubmed.ncbi.nlm.nih.gov/13593886/
12. Sudakin DL. Occupational exposure to aluminium phosphide and phosphine gas? A suspected case report and review of the literature. Hum Exp Toxicol 2005; 24:27-33.

https://pubmed.ncbi.nlm.nih.gov/15727053/

\section{Kompleksna i retka prezentacija trovanja pirinčanom tabletom: prikaz slučaja}

Feridoun Sabzi, Aghigh Heydari, Reza Heidari Moghaddam, Mohammad Rouzbahani, Atefeh Asadmobini

Istraživački centar za kardiovaskulatne bolesti, Univerzitet medicinskih nauka Kermanšah, Kermanšah, Iran

\section{S AŽETAK}

Aluminijum-fosfid, poznat kao pirinčana tableta (RT - eng.), često je sredstvo pomoću kojeg žene pokušavaju da izvrše samoubistvo u Iranu, sa visokom stopom smrtnog ishoda. U radu je prikazana pacijentkinja sa toksičnošću izazvanom pirinčanom tabletom i kompleksnim sindromom insuficijencije jetre i bubrega, obrascem Brugada sindroma, i pleuroperikardijalnim izlivom. Pacijentkinja je podvrgnuta konvencionalnom lečenju fluidnom terapijom, ispiranju želuca i trtmanu aktivnim ugljem, nakon čega je sledilo ubacivanje intraaortne balon pumpe, lečenje inotropnim lekovima i mehaničkom ventilacijom. Jedinstvene karakteristike našeg slučaja povezane su sa kombinacijom insuficijencije više organa, atipičnim EKG obrascima Brugada sindroma i pleuroperikardijalnim izlivom. Među pomenutim komplikacijama, pleurokardijalni izliv, ascites i Brugada sindrom veoma retko se dešavaju. Pacijentkinja je lečena visokim dozama inotropnih lekova i ubacivanjem intraaortne balon pumpe. Uprkos opsežnom lečenju metaboličke acidoze, svi napori nisu uspeli i pacijentkinja je umrla od iznenadnog srčanog zastoja.

Ključne reči: aluminijum-fosfid, Brugada sindrom, trovanje 